\title{
THE EFFECTS OF HOME HEATING ON ASTHMA: EVIDENCE FROM NEW ZEALAND
}

\author{
Andrea Kutinova Menclova* and Rachel Susan Webb \\ Department of Economics and Finance \\ University of Canterbury \\ Private Bag 4800, Christchurch, New Zealand \\ e-mail: andrea.menclova@canterbury.ac.nz and \\ rachel.webb@pg.canterbury.ac.nz \\ phone: (+64-3) 364 2823, fax: (+64-3) 3642635 \\ * Corresponding author
}

\begin{abstract}
New Zealand, along with the US and Australia, has one of the highest asthma rates among developed countries and previous analyses attribute this partly to insufficient home heating in certain neighborhoods. International public health and medical studies corroborate this link but strong evidence of causality is lacking. In this paper, we empirically investigate the effect of home heating on hospital asthma admissions using panel data techniques and controlling for endogeneity. The hypothesis that higher electricity prices (via less adequate heating) increase hospital asthma admissions is tested and receives strong empirical support across a number of model specifications and datasets used. (JEL Code: I12)
\end{abstract}

Keywords: Asthma, Home Heating, Electricity Price 


\section{INTRODUCTION}

New Zealand has one of the highest asthma rates in the world along with other western countries like the US, UK, and Australia (Holt and Beasley, 2002). Specifically, one in six adults and one in four children in NZ suffer from asthma symptoms and the disease is the leading cause of hospital admissions among children (Asthma and Respiratory Foundation of NZ, 2006). Approximately 130 deaths a year are caused by asthma attacks in NZ. The direct medical costs to the country of treating asthma have been estimated at $\$ 125$ million annually and including indirect costs such as lost productivity and years lost to disability brings that figure up to \$700million or around 0.7\% of GDP (Holt and Beasley, 2002).

Although asthma prevalence is the highest in wealthy countries, within countries, it is manifestly a disease of lower socio-economic groups. In NZ, asthma disproportionately affects Māori and Pacific-Islanders in both prevalence and severity. Previous research attributes this unsatisfactory state partly to poor socioeconomic conditions in certain neighborhoods and to insufficient home heating in particular (Ellison-Loschmann et al, 2004; Petronella and ConboyEllis, 2003; Butler et al, 2003; and Crane et al, 1998). Howden-Chapman et al. (2009) report that many NZ houses are colder and damper indoors than recommended by the World Health Organization and international retrospective empirical studies suggest that the lack of home heating is associated with higher asthma rates (Borooah, 2007; Thomson et al, 2009). A limited number of randomized controlled trials seem to support this hypothesis (Barton et al, 2007).

However, the evidence to date is inconclusive and many of the studies available do not control adequately for the endogeneity of home heating. Furthermore, rigorous analyses of NZ asthma data are sparse. Yet, as discussed below, NZ provides a unique setting to study the effects of home heating on asthma. The main objective of this paper is to fill the gap and 
carefully investigate the causal link between adequate home heating and hospital asthma admissions in NZ.

Our main specification is a reduced-form, panel data model which provides strong evidence of a positive relationship between a proxy for home heating and hospital asthma admissions, especially among infants. This finding withstands a series of robustness checks including different estimation procedures, changes to the definition of the dependent variable, inclusion of additional explanatory variables, and a placebo test.

\section{BACKGROUND}

For the purposes of this paper, we define home heating as deliberately raising the indoor temperature of residential properties using electric or non-electric heater types - such as heat pumps, electric columns heaters and fan heaters, wood and coal burners, and gas heaters. The main avenue for home heating to influence asthma prevalence and severity is through the effect it has on house dust mites (HDM) survival. HDM require a relatively cool and humid environment (Crane et al, 1998). NZ’s temperate, humid climate provides an ideal atmosphere for the proliferation of HDM throughout households. Adequate home heating can prevent HDM from inhabiting households by reducing humidity. Other avenues for home heating to affect asthma symptoms are through the direct effect on indoor temperature and through the effect on mold growth.

Randomized housing improvement studies have attempted to assess the causal effect of home heating on asthma rates. The Watcombe housing study conducted in the UK (Barton et al, 2007) investigated self-reported asthma rates in households with improved heating and insulation and found a statistically significant but negligible effect on asthma prevalence. Two prominent randomized controlled studies in NZ looked at the effects of housing improvement on respiratory 
conditions in general (Howden-Chapman et al, 2007) and asthma specifically (HowdenChapman et al, 2008) and found beneficial causal effects. Crane et al (1998) investigated the effect of installing a Mechanical Ventilation Heat Exchange system on the presence of HDM in NZ homes and found no significant effects. While randomized controlled studies investigate the relationship of interest directly, they typically have the following drawbacks: due to their substantial costs, the time period is often short; asthma is mainly measured by self-reports of symptoms; survey participants cannot be 'blinded' to the intervention ('treatment') which is especially problematic when relying on self-reports; and some have problems with participant compliance. Although many of the studies acknowledge and to some extent address these issues (e.g., the Watcombe study included a nurse assessment of asthma symptoms to complement a portion of the self-reports) the evidence they provide supporting the causal link between home heating and asthma deserves further investigation.

Other studies have evaluated the correlation between asthma and home heating using cross-sectional econometric methods and some have found a negative correlation (Butler, et al., 2003; Borooah, 2007). Our own analysis using the NZ General Social Survey data from 2008 indicates that self-reported household dampness and cold correlate with worse general health outcomes, even after controlling for a range of individual demographic and socio-economic factors. ${ }^{1}$ However, these studies do not fully control for the complex effects of wealth, an inherent problem with using cross-sectional data for this type of analysis. The problem stems from the fact that home heating is an endogenous determinant of asthma prevalence due to it

\footnotetext{
${ }^{1}$ For example, we find that reporting that dampness is a major problem with the house decreases the likelihood of reporting excellent health by about 5\% and reporting a 'too cold' house decreases it by $4 \%$, ceteris paribus.
} 
being highly correlated with wealth - and possibly other observable and unobservable household characteristics - which can in turn affect asthma prevalence through many potential mechanisms besides home heating. Plausible connections between wealth and health found in the asthma literature include: education, childhood fruit intake, smoking, living in polluted areas (Neidell, 2004), and underlying racial tendencies.

Our research addresses the endogeneity of home heating in a way that had not been attempted in the literature: by using electricity prices as an instrument (or a proxy) for home heating. High electricity prices reduce electricity consumption (a normal good). As home heating is a relatively large component of household electricity usage in NZ (it is the third largest component at approximately 19\%; EECA, 2010) it is likely that the quantity of home heating used will be highly price elastic. Moreover, while all major NZ cities experience cool winters, the climate is mild enough to make heating 'optional' on most days and thus price elastic. Using annual Census data from years 2001 and 2006 (Statistics NZ, 2006), we confirm that the percentage of households reporting use of electric heating has a strong negative relationship with regional electricity prices. For example, in 2001, an increase of the real electricity price by one cent per kilowatt was associated with a reduction in the proportion of households using electric heating by 7.2 percentage points (results available on request). ${ }^{2}$ Since electricity prices are not correlated with wealth and other household characteristics, the effect they have on asthma rates should solely be through the effect on home heating. We estimate the elasticity of hospital asthma admissions with respect to electricity prices below.

\footnotetext{
${ }^{2}$ Unfortunately, data on actual home heating is only available for the two Census years in our period and lacks any other time variation. Given the aggregated nature of our dataset, we could only use 20 regional observations in 2001 and 14 in 2006. This hinders any reliable instrumental variable estimation. Therefore, we rely on a reduced form approach in our analysis.
} 
A complication with estimating the reduced-form relationship between electricity prices and asthma rates empirically is that higher electricity prices may cause people to substitute towards non-electric sources of heating such as gas heaters and wood burners. While this has a potential to counteract the direct effect electricity prices would have on asthma through reduced electric heating as homes may still be heated to a comparable level, the heating appliances themselves may affect asthma. Gas heating - especially unflued varieties - can increase particulate matter in the air of homes and can also increase moisture leading to mold growth plus a higher humidity which helps HDM proliferation (NZ Ministry of Health, 2005). Wood burners may increase particulate matter in homes as well as the atmosphere outside, worsening asthma of people in the surrounding area and those inside the house. Consequently, the hypothesized relationship between electricity prices and asthma rates remains positive - via reduced heating and/or switching to less healthy heating appliances.

\section{DATA AND METHODS}

\subsection{Data}

Our data comes from several sources: hospital asthma (and, in a robustness check, cerebro-vascular disease) admissions from NZ Ministry of Health; electricity prices and gas prices from NZ Ministry of Business, Innovation, and Employment (MBIE); population statistics, median household income, and Consumer Price Index (CPI) values from Statistics NZ; 
and weather data from NZ National Institute of Water and Atmospheric Research (NIWA). The spatial unit of analysis is a District Health Board (DHB) region. ${ }^{3}$

The raw asthma admissions data contain quarterly numbers of hospital admissions where the primary diagnosis was identified as asthma separated by five-year age brackets, sex, and three ethnicity categories (Māori, Pacific Islander, Other) from July 2000 to June 2009, for each DHB. The quarters are defined as follows: first quarter (Q1) January-March, second quarter (Q2) April-June, third quarter (Q3) July-September, and fourth quarter (Q4) October-December. The second and third quarters, combined, represent NZ winter and the colder months of spring and autumn; the first and fourth quarters, combined, represent NZ summer and the warmer months of spring and autumn.

Although our results are based on hospital asthma admissions rather than asthma prevalence in general, it seems reasonable to assume the results can be generalized to give an indication of the overall asthma burden. The main reason for using hospital admissions is the availability of data but another major benefit is that the figures are (relatively) objective as they have been assessed by a health care professional. Self-reported measures of asthma prevalence may be more thorough but would suffer from the inaccuracy associated with self-assessment of health outcomes. A potential concern with the use of hospital admissions data is the sensitivity of health care visits to disposable income. However, this is not a very serious issue in NZ with free admissions to public hospitals and subsidized primary care visits (especially for children

\footnotetext{
${ }^{3}$ Between 2001 and 2010, New Zealand was administratively divided into 21 DHBs, each covering between around 30,000 (West Coast) and 450,000 (Waitemata) people. The average DHB population in 2001 was 185,000.
} 
under 6 years who typically receive free general practitioner care). ${ }^{4}$ This is another aspect that makes NZ an appealing setting for this study.

Since the literature suggests that infants and young children are the most affected by asthma and that once adulthood is reached, age has little effect on asthma, we analyze the effects on infants (0-4 years), children (5-14 years), and adults (15+ years) separately. We also present some of our results separately for the following ethnic sub-categories: Māori, Pacific Islanders, and Other. We ignore gender sub-categories as we could not find any suggestion in the literature that there should be a priori differences between the two sexes in asthma prevalence.

Age-specific population data has been obtained from Statistics NZ and allows us to express asthma admissions as rates per 10,000 individuals (per DHB). ${ }^{5}$ Unfortunately, the population data is annual whereas all our other datasets are quarterly, reducing the precision of calculated admission rates. Therefore, our preferred model specification contains the absolute number of admissions as the dependent variable and population estimates as a regressor. We report results for the asthma admissions rate in a robustness check.

\footnotetext{
4 That said, Māori generally have higher avoidable and ambulatory-sensitive hospitalization rates than non-Māori (NZ Ministry of Health, 2010). This may partly be due to nonfinancial barriers in primary care access and likely contributes to the higher asthma admission rates observed among Māori in our data. If Māori are less likely to manage health conditions themselves or to use primary care, all else equal, we would expect their hospital asthma admissions to be more elastic with respect to electricity prices. However, we are unable to confirm this hypothesis in our analysis below (see Table 2). This may be due to lower utilization of electric heating among Māori and warrants a future investigation.

${ }^{5}$ As this data was only available up to 2008, we have assigned 2008 population estimates to observations from 2009.
} 
Electricity prices were obtained from the Quarterly Survey of Domestic Electricity Prices (QSDEP; MBIE, 2010b). This survey provides quarterly retail electricity prices for each retailer purchasing from a line business between April 1998 and November 2009. Each line business services a well-defined geographical area identified in QSDEP. However, these areas do not precisely coincide with DHBs so we have re-assigned line businesses into DHBs (Table A1). ${ }^{6}$

For each area, the QSDEP also identifies which retailer is the incumbent retailer. Following advice from a representative from MBIE, we use retail prices from the incumbent retailers as our primary measure of electricity prices for a line business. Where there are multiple line-businesses within a DHB, we have created a weighted average price across incumbent retailers. The relative weight of each retailer can be estimated by the number of Installation Control Points (ICPs) each retailer controls. Data on the number of ICPs was obtained from the Electricity Commission website (NZ Electricity Commission, 2010). ${ }^{7}$ As a robustness check, we also employ a measure of retail electricity prices calculated as a weighted average of the price for each DHB across all retailers as opposed to just the incumbent retailers. Unfortunately, not all retailers have price data available; in some DHB/quarter observations, only $4 \%$ of the market had price data available. This is discussed further below. To obtain a real price

\footnotetext{
${ }^{6}$ Most DHBs are matched very closely to one or more line businesses but there are a couple that do not fit perfectly. This is especially evident on the Lakes/Waikato border and the Southland/West Coast border. However, this should not be a cause of concern because the area of difference is very sparsely populated and given that the electricity price data is only an estimate, the loss in accuracy due to a different border definition is trivial.

${ }^{7}$ This data contains the number of ICPs per retailer for each Network Supply Point (NSP). As each line business controls several NSPs, we have summed the number of ICPs per NSP to each line business.
} 
measure, we adjust both electricity price estimates for inflation using national, quarterly CPI provided by Statistics NZ. ${ }^{8}$

The NZ electricity market relies largely on hydro power with $57 \%$ of electricity being generated at hydro power plants, on average. The next largest source of electricity is gas at $20 \%$ followed by geothermal energy at $11 \%$, coal at $7 \%$, and other sources such as wind at $5 \%$ (MBIE, 2010a). Due to the high proportion of energy coming from hydro sources, the electricity market is heavily influenced by rainfall in the few relatively compact lake/river regions where the majority of hydro power is generated. Over $80 \%$ is generated within four regions that are mostly sparsely populated: the Clutha Lakes (14\%), Lake Manapouri (13\%) ${ }^{9}$, the Waikato River (21\%) and the Waitaki Lakes (33\%). Also, the majority of hydro generation takes place in the South Island (where the Clutha Lakes, Lake Manapouri and Waitaki Lakes lie) and is transmitted to the much more populated North Island (representing about $64 \%$ of electricity demand) through a high voltage direct current link between the two islands. If the electricity market is highly supply-driven as evidenced in Hogan and Meade (2007), electricity prices are likely to be strongly affected by weather conditions at the source of power generation (affecting supply) but not necessarily by weather at the end-user's residence (affecting demand) which may be very different.

\footnotetext{
${ }^{8}$ For the purposes of regional CPI calculations, NZ is only separated into the three main cities (Auckland, Wellington and Christchurch) and the rest of the North and South Islands and estimates are only available from the second quarter of 2006. This makes regional CPI estimates of little use in our study.

${ }^{9}$ A majority of the electricity produced at Lake Manapouri is, however, used directly by the Tiwai Point aluminium smelter rather than released into the national grid.
} 
Nevertheless, to allow for the theoretical possibility that weather simultaneously impacts electricity prices and asthma admissions in a particular location, we control for DHB-level quarterly weather conditions in all of our models. The average values per DHB/quarter have been calculated from monthly weather records obtained from NIWA's CliFlo database. Our main model contains information on the mean temperature, mean daily minimum temperature, and mean daily maximum temperature at a weather station representing each DHB (typically located in the largest town of each DHB). In a robustness check, we add information on average monthly rainfall and average 9am temperature in each DHB/quarter (unfortunately, this information is missing for Counties Manukau and Taranaki DHBs so is not included in our main model).

To at least partly control for the simultaneous effects of wealth on home heating and health, we use annual, DHB-level median household income estimates from Statistics NZ in all of our models. This is a grossly aggregated measure of economic status but still the best proxy available. To conduct a placebo test (explained in detail below), we have obtained data on cerebrovascular disease admissions, of which stroke admissions are a major component, from the Ministry of Health.

Gas price data was obtained from MBIE and adjusted for inflation using the national CPI. The dataset contains monthly gas prices for 31 cities and towns in the North Island in 2001. We use the data from cities and towns to represent the DHBs they are in, which provides data for all North Island DHBs except Wairarapa. Unfortunately, there are many missing observations so in total only $178 \mathrm{DHB} /$ quarter cells can be used. No data is available on the number of customers subscribing to each price plan in individual towns and cities, so there is no way to produce an accurate weighted average price. To address this limitation, two measures of gas price were 
produced: 1. the lowest price in the DHB and 2. an un-weighted average of all pricing plans available in the DHB. Both approaches are problematic but are the best achievable with limited data.

\subsection{Methods}

In our main specification, we regress asthma admissions on real electricity prices, initially using Ordinary Least Squares.

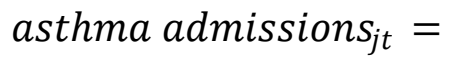

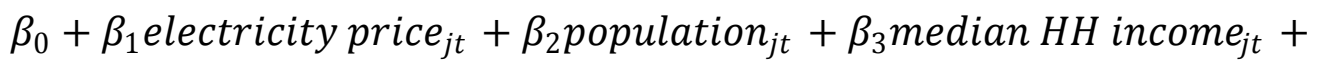

$\beta_{4}$ mean temp $_{j t}+\beta_{5}$ min.temp $j t+\beta_{6}$ max.temp $_{j t}+\gamma+\delta+\theta+\varepsilon_{j t}$

where $j$ indexes DHB regions and $t$ quarters. As long as the dependent variable is the number of admissions (as opposed to the rate of admissions), it is critical that population be included as a regressor. In addition, we control for the real median weekly household income, mean temperature, mean daily minimum temperature, and mean daily maximum temperature in all of our models in recognition of their potentially simultaneous effects on home heating and health. Regional $(\gamma)$, yearly $(\delta)$, and quarterly $(\theta)$ fixed effects are included to control for time-invariant DHB characteristics and for national time trends and seasonal effects, respectively. We weight observations by population to obtain nationally representative results. As some regions have more variable asthma rates than others, we correct standard errors for heteroskedasticity and cluster them by DHB.

In a series of robustness analyses, we adjust the functional form and estimation method of the main specification above, including the following checks: transforming the dependent variable to admission rate; transforming the model to log-linear, log-log and linear-log 
specifications; adding a one-quarter lag of the dependent variable as an explanatory variable; and estimating the regressions with Panel-Corrected Standard Errors. We repeat this process with the dependent variable stratified by age and ethnicity with the corresponding population statistics.

To check that our results are not unduly sensitive to the definition of our main explanatory variable, we repeat the baseline regression with a more comprehensive weightedaverage electricity price. As mentioned in the previous section, this measure is problematic due to missing data. To address this issue, we rerun the model on two different subsamples with problematic observations omitted. First, we drop the five DHBs with the smallest average percentage of the market accounted for (all less than 60\%); second, we drop all DHB/quarter cells with the percentage of the market accounted for less than $30 \%$.

To check whether the effect of electricity prices on asthma admissions is due to the 'quantity' of home heating or substitution to alternative fuels, we include data on gas prices as an additional explanatory variable. If the 'substitution effect' is the more important of the two, we would expect to see the magnitude and significance of the coefficient on electricity price drop notably, and the coefficient on gas prices to be negative and significant (as gas heating is less beneficial to asthma-sufferers than electric heating).

In a placebo test, we check whether the method used for asthma gives a significant relationship between home heating and cerebrovascular disease, pointing to a spurious correlation in our asthma findings. Cerebrovascular disease was selected because it is an acute condition so the time of admission should be a reasonable estimate of the onset of the condition, it is common, and, most importantly, it should not be correlated with home-heating.

If home heating is driving the correlation between asthma and electricity price, then electricity price should have a larger effect in colder regions (mostly the South Island) and/or 
quarters (winter quarters Q2 and Q3). To test for this, we run a series of regressions interacting electricity prices with both regional and seasonal dummies.

\section{RESULTS}

\subsection{Descriptive findings}

Our descriptive findings are consistent with the literature in showing that asthma is the highest amongst infants and children (Figure 1). In particular, there is a distinctive trend of asthma admissions decreasing until adulthood is reached and changing very little afterwards.

\section{[Please insert Figure 1 somewhere here]}

As previously documented, Māori are disproportionately represented in asthma admission statistics. In our sample, Māori only represent $15 \%$ of the NZ population but $34 \%$ of hospital asthma admissions. Finally, asthma admissions decreased somewhat over the time period studied (Figure 2). This decline may partly be due to improvements in personal management or primary treatment of asthma but likely also reflects better home insulation and heating practices in recent years. Highly subsidized (or even free) insulation has become available to 'at risk' households under the Warm Up New Zealand: Healthy Homes project and, as we discuss in more detail below, the NZ Ministry for the Environment has also recently introduced required standards for non-electric home heaters. Warmer homes as well as less air pollution may be contributing to the decline in asthma admissions observed in Figure 2.

[Please insert Figure 2 somewhere here]

There is substantial variation in the real electricity price both over time and across DHBs (Figure 3 displays the minimum, unweighted mean, and maximum price as well as prices in two 
North Island DHBs and two South Island DHBs - one rural and one urban in each). For all DHBs, we can observe a sizeable increase between July 2000 and June 2009 by about 6c/kWh (or over 30\%), on average. This is comparable in magnitude to the difference between the maximum and the minimum electricity price in any given quarter. Sparsely populated DHBs tend to have substantially higher electricity prices than DHBs with a large urban center (e.g., compare Northland vs. Auckland in the North Island or West Coast vs. Canterbury in the South Island; Figure 3). Importantly for the identification of our reduced form models, the timing of price increases varies widely across DHBs. The mean price of the incumbent retailer is very similar to the mean weighted price of all retailers within a DHB - both are just slightly over 19c/kWh (Table 1).

\section{[Please insert Figure 3 somewhere here]}

NZ has a relatively cool climate (Table 1 ) with the mean daily temperature just over $13^{\circ} \mathrm{C}$ $\left(55^{\circ} \mathrm{F}\right)$ and the mean daily minimum around $9^{\circ} \mathrm{C}\left(48^{\circ} \mathrm{F}\right)$ and maximum around $18^{\circ} \mathrm{C}\left(64^{\circ} \mathrm{F}\right)$. As mentioned above, we control for DHB-level weather patterns in all of our models.

[Please insert Table 1 somewhere here]

\subsection{Reduced-form model}

As hypothesized, the effect of electricity prices on asthma admissions is positive and highly significant in our baseline specification (first column of Table 2), indicating that if the real electricity price increases by one cent per kilowatt, holding population constant, the number of hospital admissions for asthma will increase by around six people, on average, in any quarter in any DHB region. This represents an 8\% increase from the average of 82 . This result withstands 
most robustness checks (available on request). For example, adding a lag of the dependent variable does not substantially affect the magnitude or significance of the coefficient on price. Similarly, various log transformations of the dependent and independent variables do not greatly affect the significance of the main relationship. Applying the coefficients to an average region and quarter produces similar magnitudes of effects as the linear model. However, converting the dependent variable to the form of rates (second column of Table 2) eliminates the significance of the price coefficient. It is plausible that this result is due to the fact that population numbers are annual rather than quarterly and hence produce inaccuracies in the measurement of rates. Also, including population estimates in the denominator of the dependent variable rather than as an explanatory variable makes the specification of the role of population less flexible.

\section{[Please insert Table 2 somewhere here]}

Repeating our baseline regression on cerebrovascular disease admissions (third column of Table 2) produces an insignificant - and negative - coefficient on electricity price. This suggests that the results of our baseline regression are not merely due to spurious correlation and thus supports our main findings above. It is interesting to note that the included temperature variables are highly significant in the placebo test - consistent with seasonality of cerebrovascular disease (Oberg et al., 2000).

Median household income significantly reduces the number of asthma admissions in a DHB (Table 2). This is consistent with previous observations that asthma disproportionately affects lower socio-economic groups. None of our weather variables (mean temperature, mean daily minimum temperature, and mean daily maximum temperature in Table 2 and mean 9am temperature and total rainfall in a robustness check available on request) come close to reaching statistical significance and their addition to the model does not change the coefficient on 
electricity price. The robustness of the price coefficient to the inclusion of local weather information is consistent with supply-driven electricity prices in NZ where local weather does not substantially affect local electricity prices. The coefficients on the year dummy variables become increasingly negative for later years, confirming that asthma admissions have been decreasing over time (results available on request). The coefficients on quarterly dummies indicate that asthma admissions are highest in Q1 (January to March) and lowest in Q3 (July to September) indicating that asthma is a bigger problem in the warmer months than the colder ones. This is most likely due to seasonal variation in pollen exposure which is known to trigger asthma attacks. Coefficients on regional dummies suggest that South Canterbury has consistently the highest asthma admissions and Waitemata and Auckland have the lowest, ceteris paribus.

Next, we apply the baseline specification to the separate age and ethnicity categories (columns 4-10 of Table 2). The effect of electricity price on asthma admissions is positive for all age groups but decreases with age and is only statistically significant for infants and children. In particular, an increase in the real electricity price by one cent per kilowatt increases asthma hospital admissions by nearly $13 \%$ among infants, $8 \%$ among children, and over $3 \%$ among adults. The large effect on infants makes intuitive sense firstly because infants are by far the most likely to be admitted to hospital for asthma and also because infants probably spend the most time at home and so are affected the most by housing conditions. Given the prominence of the result for infants, we repeat all of our robustness checks for the infant subsample and find the main finding very robust. Results from ethnicity-specific regressions show only the majority 'other ethnicity' category to have a positive and significant coefficient on price. However, the 
electricity price coefficient is significant and potentially very large for Pacific Islander infants. Māori infants also seem more responsive than Māori children and adults.

To verify that our results are not too sensitive to the definition of the DHB-level electricity price, we estimate the baseline regressions for all admissions and infant admissions using the more comprehensive weighted-average electricity price (Table A2). As mentioned above, we use three different subsamples for these estimations (depending on how representative electricity data we could obtain). Overall, while the estimated effects are statistically weak for all admissions (and vary with sample changes), they remain significant, positive, and reasonably large for infant admissions.

Results of the models including gas prices (available on request) tentatively indicate that substitution from electric heating to gas heating is not the cause of the relationship between electricity prices and asthma admissions. In particular, once the substantially reduced sample size is accounted for, the inclusion of gas prices as an explanatory variable has negligible effect on the size and significance of the electricity price coefficient and the gas price coefficient is itself statistically insignificant.

\section{[Please insert Table 3 somewhere here]}

The addition of seasonal and regional interactions with the electricity price (Table 3) suggests that home heating plays an important role behind the observed relationship between electricity prices and asthma admissions. Although there are fewer asthma admissions in winter (as indicated by the negative coefficients on Q2 and Q3 in column 1), the sensitivity of asthma admissions to electricity price seems to increase during winter (as indicated by the positive, but statistically insignificant, coefficients on Price*Q2 and Price*Q3). This is at least weakly consistent with our hypothesis that poor home heating contributes to increased asthma 
admissions. Interacting electricity price with a dummy variable for the South Island (column 2) produces a negative coefficient, which seemingly contradicts our hypothesis that asthma admissions are more sensitive to electricity price in colder regions. However, the fact that most admissions occur during summer may be confounding this result. To address this, we add a three-way interaction between electricity price, winter, and the South Island (column 3) and find that: 1. Electricity prices do matter more during winter (the Price*Winter coefficient is now highly statistically significant) and 2. If anything, electricity prices during winter have a greater positive effect on asthma admissions in the South Island than in the North Island. Finally, interacting electricity price with DHB regions, we have been able to produce a measure of the elasticity of asthma admissions with respect to the electricity price in each region (Figure A1; darker colors represent higher elasticity). Although not overwhelmingly clear, there appears to be a pattern of more Southern regions having higher elasticities. It is important to keep in mind that the estimated elasticity is related to the proportion of people who use electric heating (Figure A2; darker colors represent higher proportions) and are therefore affected by increasing electricity price.

\section{CONCLUSION}

Our results imply that hospital asthma admissions are strongly correlated with electricity prices and robustness checks of the functional form indicate that the relationship is stronger and more robust for infants than it is for the general population. However, even the general findings remain qualitatively consistent across model specifications. Moreover, previous studies suggest that childhood asthma has long-term impacts on adult health (Fletcher et al, 2010) and that chronic conditions developed in childhood are in a large part responsible for the socio-economic 
gradient in health (Case et al, 2002; Case et al, 2005) and likely also for the intergenerational transmission of socioeconomic status (Currie, 2009).

Estimates of seasonal and regional interactions with electricity price support the hypothesis that electricity prices affect asthma through their effects on home heating. This is consistent with our analysis of Census data suggesting a strong negative relationship between electricity prices and electric heating use. Although asthma admissions are higher in summer, the effect of electricity prices on asthma admissions is higher in winter. There also appears to be a suggestive regional pattern with the elasticity of asthma admissions with respect to electricity price increasing towards the colder South.

Further work is warranted to fully investigate the relationship between asthma and indoor heating for school children (age 5+ in NZ). These children spend considerable amount of time in school and while our model is not strictly limited to electricity usage at home, the incentive of a school to save on electricity by reducing heating is presumably less direct than at home. School terms, in particular the start of the school year, have a well-documented effect on asthma hospital admissions (Julious et al, 2007). It has been suggested that the increase in social contacts and the associated increase in viral susceptibility is the culprit (Lincoln et al, 2006). It is also plausible that being at school might influence the reported number of asthma attacks and admissions without affecting the underlying prevalence or severity of asthma if schools are more inclined to refer a child for medical intervention than parents who may feel more comfortable handling the symptoms themselves. An interesting area of investigation would be the effect school terms have on asthma admissions via changes to the indoor heating children are exposed to.

Another possibility to consider is that insulation or substitution to more efficient forms of heating may be influencing our results. High electricity prices could encourage people to invest 
in more energy efficient forms of heating such as heat pumps and/or better insulation of their homes. Although this is a probable reaction over a longer period, it seems unlikely that many people would make these adjustments in the quarter of a price increase. Therefore, it is doubtful that the effect of people improving their insulation or form of heating in the same season would bias our results. Moreover, even if that was the case, it would bias our results downwards and make them conservative estimates of the effects of indoor temperature on asthma admissions.

Our data ends in 2009 and there have since been changes in the use of non-electric sources of heating. In 2004, the NZ Ministry for the Environment introduced National Environmental Standards regulating the use of wood burners (NZ Ministry for the Environment, 2011). These standards require certain wood burner efficiency in order to limit the emissions of pollutants into the air. A recent report (NZ Ministry for the Environment and Statistics New Zealand, 2014) concludes that air quality in New Zealand did indeed improve substantially between 2006 and 2012 and attributes this partly to a reduced use of wood and coal burners. Hence, high electricity prices are now less likely to induce substitution towards non-electric heating sources which trigger asthma attacks through their emission of pollutants. On the other hand, this may mean that indoor temperature in residential properties has become even more elastic to electricity prices - offsetting some of the beneficial effect. A follow-up study using more recent data could investigate the relative magnitude of these effects and analyze implications for the reduced-form relationship between electricity prices and hospital asthma admissions. 
Finally, older people with chronic asthma can develop a Chronic Obstructive Pulmonary Disease (COPD). While we may be missing some cases of asthma in the elderly by not including COPD diagnoses in our analysis, an inclusion of COPD would also be problematic because its definition is much broader than chronic asthma and COPD patients also receive different treatment than asthma patient. A future study focused on the older population should investigate the relationship between home heating and COPD carefully. 


\section{BIBLIOGRAPHY}

Asthma and Respiratory Foundation of New Zealand (Inc.) 2006. Trying to catch our breath: The burden of preventable breathing diseases in children and young people. Asthma and Respiratory Foundation of New Zealand (Inc.): Wellington.

Barton A, Basham M, Foy C, Buckingham K, Somerville M, Torbay Healthy Housing Group. 2007. The Watcombe Housing Study: the short term effect of improving housing conditions on the health of residents. Journal of Epidemiology and Community Health $\mathbf{6 1}$ : 771-777.

Borooah VK. 2007. Health and wealth in the north of Ireland: Is there a 'social gradient' to health outcomes? Economic and Social Review 38 : 85-105.

Butler S, Williams M, Tukuitonga C, Paterson J. 2003. Problems with damp and cold housing among Pacific families in New Zealand. The New Zealand Medical Journal 116.

Case A, Lubotsky D, Paxson C. 2002. Economic status and health in childhood: The origins of the gradient. American Economic Review 92 : 1308-1334.

Case A, Fertig A, Paxson C. 2005. The lasting impact of childhood health and circumstances. Journal of Health Economics 24 : 365-389.

Crane J, Ellis I, Siebers R, Grimmet D, Lewis S, Fitzharris P. 1998. A pilot study of the effect of mechanical ventilation and heat exchange on house-dust mites and Der p 1 in New Zealand homes. Allergy 53 : 755-762.

Currie J. 2009. Healthy, wealthy, and wise: Socioeconomic status, poor health in childhood, and human capital development. Journal of Economic Literature 47 : 87-122.

Energy Efficiency and Conservation Authority (EECA). 2010. Energy end use database. http://enduse.eeca.govt.nz/default.aspx [February 2011].

Ellison-Loschmann L, King R, Peirce N. 2004. Regional variations in asthma hospitalisations among Maori and non-Maori. Journal of the New Zealand Medical Association 117. 
Fletcher J, Green J, Neidell M. 2010. Long term effects of childhood asthma on adult health. Journal of Health Economics 29 : 377-387.

Hogan S, Meade R. 2007. Vertical integration and market power in electricity markets. New Zealand Institute for the Study of Competition and Regulation working paper.

Holt S, Beasley R. 2002. The burden of asthma in New Zealand. Asthma and Respiratory Foundation of New Zealand (Inc.) and Adis International Ltd.: Auckland.

Howden-Chapman P, Matheson A, Crane J, Viggers H, Cunningham M, Blakely T, Cunningham C, Woodward A, Saville-Smith K, O'Dea D, Kennedy M, Baker M, Waipara N, Chapman R, Davie G. 2007. Effect of insulating existing houses on health inequality: cluster randomised study in the community. British Medical Journal 334 : 1-9.

Howden-Chapman P, Pierse N, Nicholls S, Gillespie-Bennett J, Viggers H, Cunningham M, Phipps R, Boulic M, Fjällström P, Free S, Chapman R, Lloyd B, Wickens K, Shields D, Baker M, Cunningham C, Woodward A, Bullen C, Crane J. 2008. Effects of improved home heating on asthma in community dwelling children: randomised controlled trial. British Medical Journal 337 : 1-9.

Howden-Chapman P, Viggers H, Chapman R, O’Dea D, Free S, O’Sullivan K. 2009. Warm homes: drivers of the demand for heating in the residential sector in New Zealand. Energy Policy 37 : 3387-3399.

Julious SA, Osman LM, Jiwa M. 2007. Increases in asthma hospital admissions associated with the end of summer vacatio for school-age children with asthma in two cities from England and Scotlad. Public Health 121 : 482-484.

Lincoln D, Morgan G, Sheppeard V, Jalaludin B, Corbett S, Beard J. 2006. Childhood asthma and return to school in Sydney, Australia. Public Health 120 : 854-862.

Neidell M. 2004. Air pollution, health, and socio-economic status: the effect of outdoor air quality on childhood asthma. Journal of Health Economics 23 : 1209-1236.

New Zealand Electricity Commission. 2010. http://www.electricitycommission.govt.nz/ [May 2010]. 
MBIE. 2010a. Energy Data File. http://www.med.govt.nz/sectors-industries/energy/energymodelling/publications/energy-data-file [April 2013].

MBIE. 2010b. Quarterly Survey of Domestic Electricity Prices. http://www.med.govt.nz/ [March 2010].

New Zealand Ministry for the Environment and Statistics New Zealand. 2014. New Zealand's Environmental Reporting Series: 2014 Air domain report.

New Zealand Ministry for the Environment. 2011. New Zealand Domestic Solid Fuel Burner Authorisation Manual. Wellington: Ministry for the Environment.New Zealand Ministry of Health. 2010. Tatau Kahukura: Māori Health Chart Book 2010, 2nd Edition.

New Zealand Ministry of Health. 2005. Unflued gas heaters and your health. http://www.moh.govt.nz/moh.nsf/indexmh/unflued-gas-heaters-may05 [May 2010].

Oberg AL, Ferguson JA, McIntyre LM, Horner RD. 2000. Incidence of Stroke and Season of the Year: Evidence of an Association. American Journal of Epidemiology 152 : 558-564.

Petronella SA, Conboy-Ellis K. 2003. Asthma epidemiology: risk factors, case finding, and the role of asthma coalitions. The Nursing Clinics of North America 38 : 725-735.

Statistics New Zealand. 2006. Census. http://www.stats.govt.nz/census.aspx [March 2010].

Thomson H, Thomas S, Sellstrom E, Petticrew M. 2009. The health impacts of housing improvement: A systematic review of intervention studies from 1887 to 2007. American Journal of Public Health 99 : S681-692. 
Figure 1.

Number of Hospital Asthma Admissions by Age

Cumulative National Admission Numbers for July 2000 - June 2009

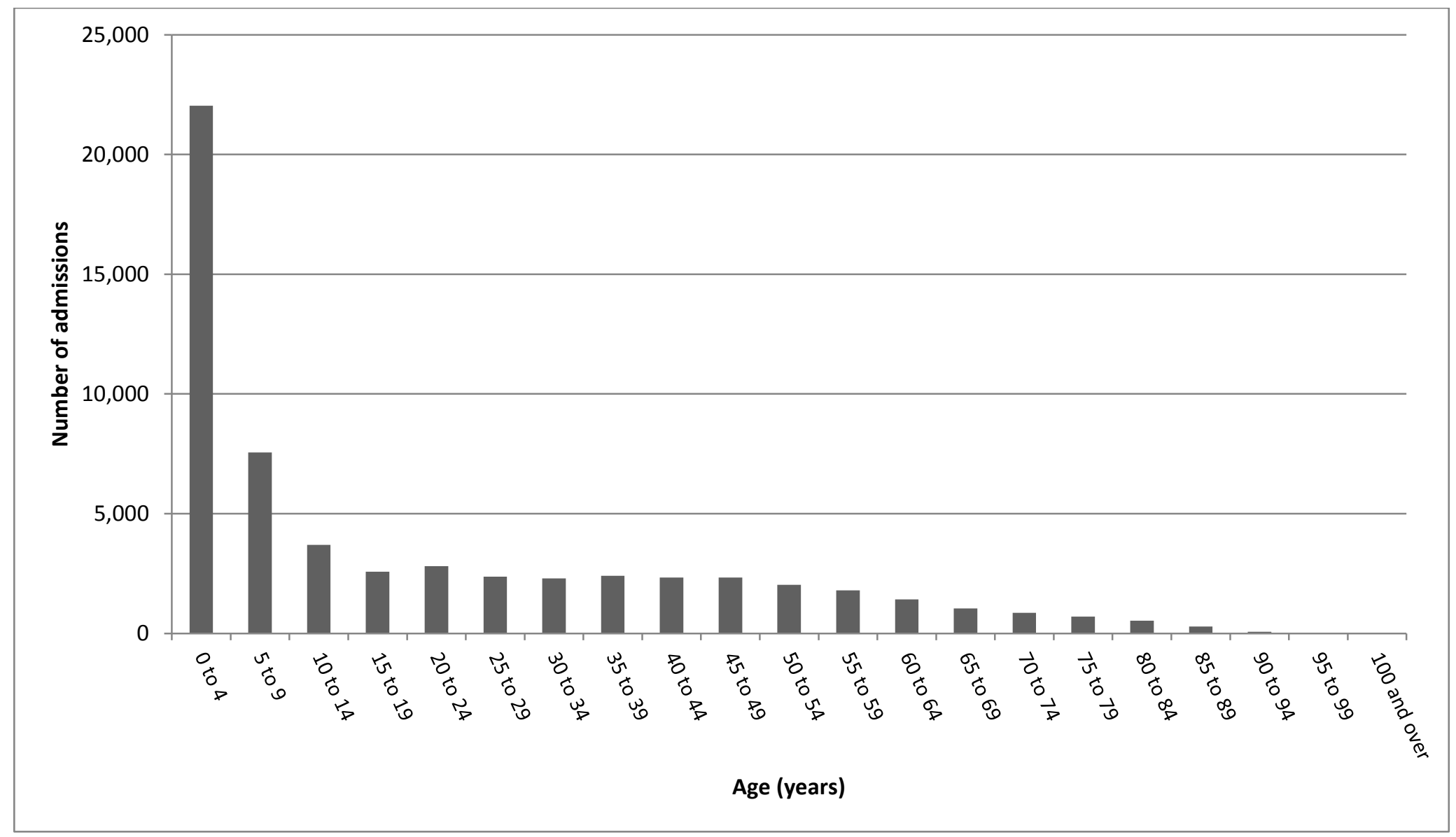


Figure 2.

Annual Numbers of Hospital Asthma Admissions

July 2000 - June 2009

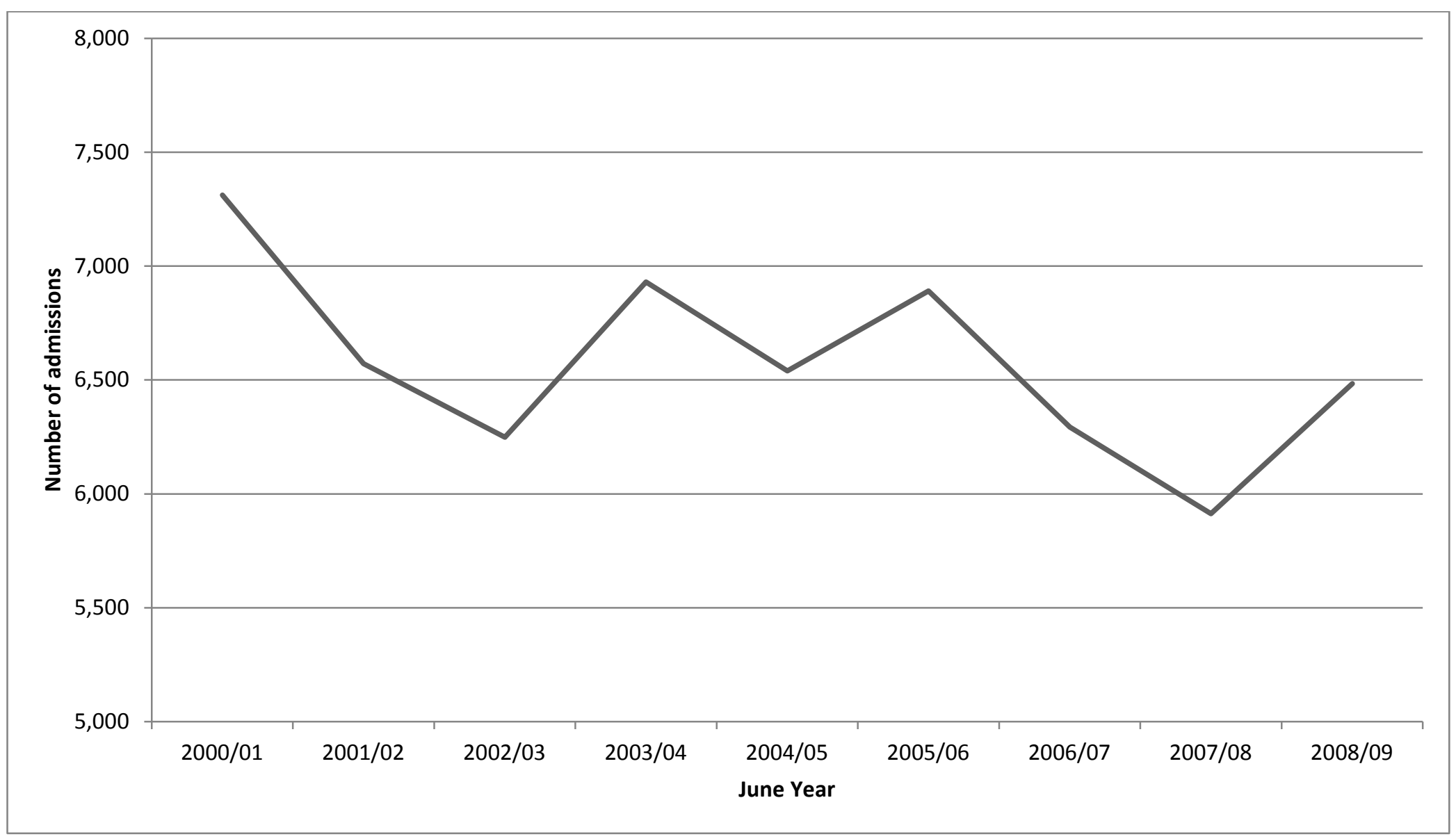




\section{Figure 3.}

Time and Spatial Variation of the Real Electricity Price July 2000-June 2009
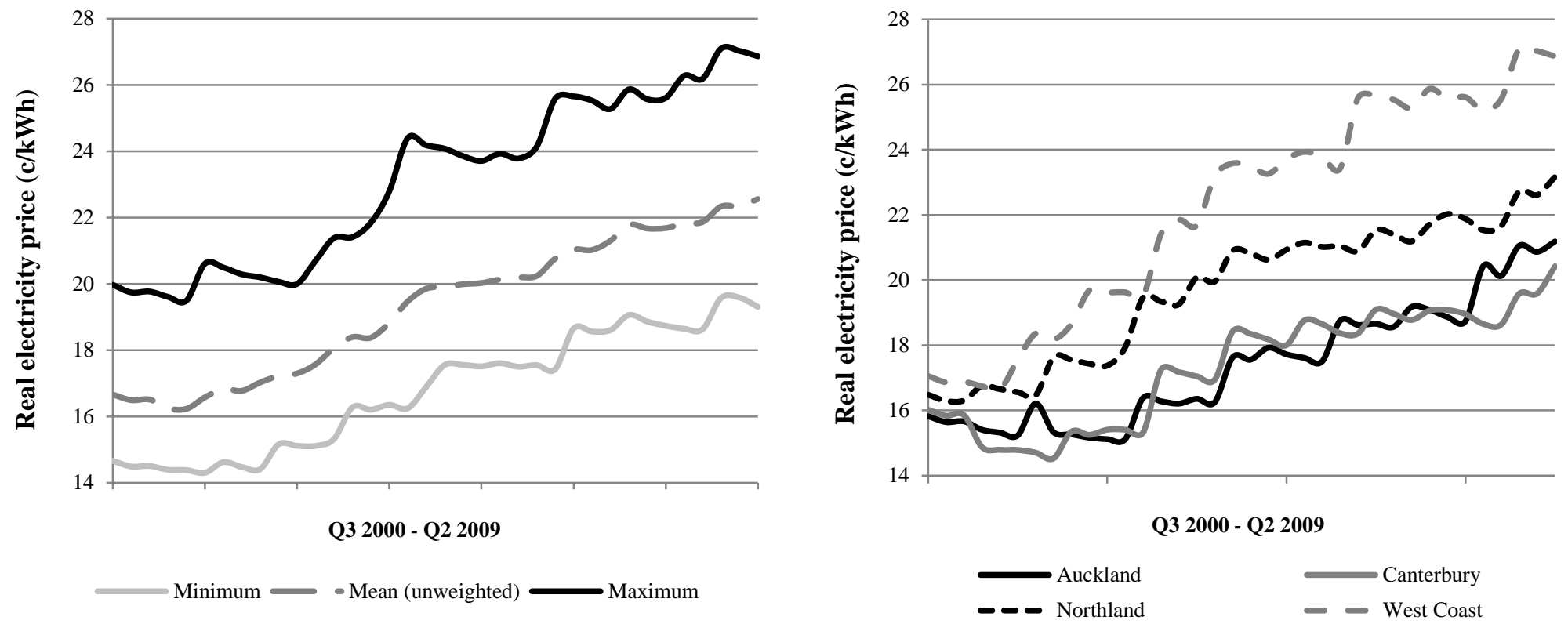


\section{Table 1.}

\section{Descriptive Statistics}

July 2000 - June 2009

\begin{tabular}{l|c} 
Variable & $\begin{array}{c}\text { Mean } \\
\text { (Standard deviation) }\end{array}$ \\
\hline All asthma admissions & 81.8 \\
& $(65.2)$ \\
Infant asthma admissions & 30.5 \\
& $(25.3)$ \\
Real electricity price (c/kWh) of the incumbent & 19.3 \\
retailer & $(2.7)$ \\
All retailer (weighted) real electricity price (c/kWh) & 19.1 \\
Population (1,000s) & $(2.7)$ \\
Infant population $(1,000 s)$ & 204.6 \\
Real median weekly household income $(\$)$ & $(155.2)$ \\
& 14.4 \\
Mean temperature $\left({ }^{\circ} \mathrm{C}\right)$ & $(11.3)$ \\
Mean daily min. temperature $\left({ }^{\circ} \mathrm{C}\right)$ & 990.5 \\
Mean daily max. temperature $\left({ }^{\circ} \mathrm{C}\right)$ & $(143.1)$ \\
& 13.3 \\
& $(3.3)$ \\
& 8.8 \\
& $(3.4)$ \\
& 17.8 \\
& \\
& \\
& \\
&
\end{tabular}

The unit of analysis is a DHB/quarter. 
Table 2.

\section{The Effects of Electricity Prices on Hospital Asthma Admissions DHB-Level Analysis, July 2000 - June 2009}

\begin{tabular}{|c|c|c|c|c|c|c|c|c|}
\hline & $\begin{array}{l}\text { All asthma } \\
\text { admissions }\end{array}$ & $\begin{array}{l}\text { All asthma } \\
\text { admissions } \\
\text { per } 10,000 \\
\text { population }\end{array}$ & $\begin{array}{l}\text { Cerebrovascul } \\
\text { ar admissions } \\
\text { (placebo test) }\end{array}$ & $\begin{array}{l}\text { Infant (0-4 } \\
\text { years) } \\
\text { asthma } \\
\text { admissions }\end{array}$ & $\begin{array}{l}\text { Child (5- } \\
14 \text { years) } \\
\text { asthma } \\
\text { admissions }\end{array}$ & $\begin{array}{l}\text { Adult }(15+ \\
\text { years) } \\
\text { asthma } \\
\text { admissions }\end{array}$ & $\begin{array}{l}\text { Māori } \\
\text { asthma } \\
\text { admissions }\end{array}$ & $\begin{array}{l}\text { Pacific } \\
\text { Islander } \\
\text { asthma } \\
\text { admissions }\end{array}$ \\
\hline $\begin{array}{l}\text { Real electricity price } \\
\text { (c/kWh) }\end{array}$ & $\begin{array}{c}6.436 * * * \\
(2.172)\end{array}$ & $\begin{array}{c}0.025 \\
(0.081)\end{array}$ & $\begin{array}{c}-0.364 \\
(1.790)\end{array}$ & $\begin{array}{l}3.812^{*} \\
(1.891)\end{array}$ & $\begin{array}{l}1.192 * * \\
(0.544)\end{array}$ & $\begin{array}{c}1.205 \\
(0.909)\end{array}$ & $\begin{array}{c}0.699 \\
(0.939)\end{array}$ & $\begin{array}{c}0.252 \\
(0.727)\end{array}$ \\
\hline $\begin{array}{l}\text { Implied change from } \\
\text { baseline }\end{array}$ & $7.9 \%$ & $0.6 \%$ & $-0.3 \%$ & $12.5 \%$ & $7.7 \%$ & $3.4 \%$ & $2.5 \%$ & $2.2 \%$ \\
\hline $\begin{array}{l}\text { Relevant population } \\
(1,000 \mathrm{~s})\end{array}$ & $\begin{array}{c}0.565 * * * \\
(0.137)\end{array}$ & - & $\begin{array}{c}0.232 \\
(0.203)\end{array}$ & $\begin{array}{c}1.564 \\
(1.908)\end{array}$ & $\begin{array}{c}1.125^{* * *} \\
(0.360)\end{array}$ & $\begin{array}{c}0.253 * * * \\
(0.071)\end{array}$ & $\begin{array}{c}1.105 \\
(0.706)\end{array}$ & $\begin{array}{c}0.685^{* * *} \\
(0.074)\end{array}$ \\
\hline $\begin{array}{l}\text { Real median weekly } \\
\text { household income (\$) }\end{array}$ & $\begin{array}{l}-0.058^{*} \\
(0.028)\end{array}$ & $\begin{array}{c}-0.002 * * * \\
(0.001)\end{array}$ & $\begin{array}{l}-0.042 \\
(0.038)\end{array}$ & $\begin{array}{l}-0.031 \\
(0.020)\end{array}$ & $\begin{array}{l}-0.009 \\
(0.008)\end{array}$ & $\begin{array}{c}-0.030 * * \\
(0.010)\end{array}$ & $\begin{array}{l}-0.026^{*} \\
(0.014)\end{array}$ & $\begin{array}{l}-0.017 \\
(0.017)\end{array}$ \\
\hline $\begin{array}{l}\text { Mean temperature } \\
\left({ }^{\circ} \mathrm{C}\right)\end{array}$ & $\begin{array}{c}1.614 \\
(53.942)\end{array}$ & $\begin{array}{c}0.073 \\
(1.498)\end{array}$ & $\begin{array}{c}81.045^{* *} \\
(28.252)\end{array}$ & $\begin{array}{c}19.419 \\
(38.857)\end{array}$ & $\begin{array}{c}-4.999 \\
(12.979)\end{array}$ & $\begin{array}{l}-18.453 \\
(25.910)\end{array}$ & $\begin{array}{l}-13.082 \\
(15.584)\end{array}$ & $\begin{array}{c}-0.454 \\
(22.937)\end{array}$ \\
\hline $\begin{array}{l}\text { Mean daily min. } \\
\text { temperature }\left({ }^{\circ} \mathrm{C}\right)\end{array}$ & $\begin{array}{c}-1.434 \\
(26.734)\end{array}$ & $\begin{array}{l}-0.017 \\
(0.754)\end{array}$ & $\begin{array}{l}-37.602 * * \\
(13.962)\end{array}$ & $\begin{array}{c}-9.768 \\
(19.757)\end{array}$ & $\begin{array}{c}3.594 \\
(6.295)\end{array}$ & $\begin{array}{c}7.656 \\
(14.039)\end{array}$ & $\begin{array}{c}6.946 \\
(7.950)\end{array}$ & $\begin{array}{c}0.802 \\
(12.051)\end{array}$ \\
\hline $\begin{array}{l}\text { Mean daily max. } \\
\text { temperature }\left({ }^{\circ} \mathrm{C}\right)\end{array}$ & $\begin{array}{c}-5.949 \\
(27.066)\end{array}$ & $\begin{array}{l}-0.137 \\
(0.753)\end{array}$ & $\begin{array}{c}-42.823 * * * \\
(14.696)\end{array}$ & $\begin{array}{l}-10.432 \\
(19.782)\end{array}$ & $\begin{array}{c}0.722 \\
(6.503)\end{array}$ & $\begin{array}{c}6.632 \\
(13.898)\end{array}$ & $\begin{array}{c}5.729 \\
(7.628)\end{array}$ & $\begin{array}{c}-3.140 \\
(10.607)\end{array}$ \\
\hline Observations & 720 & 720 & 720 & 720 & 720 & 720 & 720 & 720 \\
\hline
\end{tabular}

The unit of analysis is a DHB/quarter. White diagonal robust standard errors clustered by DHB are reported in parentheses. *, **, and *** indicate statistical significance at $90 \%, 95 \%$, and $99 \%$ confidence levels, respectively. 


\section{Table 3.}

\section{The Effects of Electricity Prices on Hospital Asthma Admissions \\ DHB-Level Analysis, July 2000 - June 2009 Seasonal and Regional Interactions}

\begin{tabular}{|c|c|c|c|}
\hline & $\begin{array}{l}\text { All asthma } \\
\text { admissions }\end{array}$ & $\begin{array}{l}\text { All asthma } \\
\text { admissions }\end{array}$ & $\begin{array}{l}\text { All asthma } \\
\text { admissions }\end{array}$ \\
\hline $\begin{array}{l}\text { Real electricity price } \\
(\mathrm{c} / \mathrm{kWh})\end{array}$ & $\begin{array}{l}6.078 * * \\
(2.535)\end{array}$ & $\begin{array}{c}10.396 * * * \\
(3.312)\end{array}$ & $\begin{array}{l}8.343 * * \\
(3.485)\end{array}$ \\
\hline Quarter 2 & $\begin{array}{c}-93.211 * * * \\
(19.274)\end{array}$ & $\begin{array}{l}-49.604 * * * \\
(13.160)\end{array}$ & - \\
\hline Quarter 3 & $\begin{array}{c}-117.719 * * * \\
(25.971)\end{array}$ & $\begin{array}{c}-72.503 * * * \\
(16.616)\end{array}$ & - \\
\hline Quarter 4 & $\begin{array}{c}-8.695 \\
(13.947)\end{array}$ & $\begin{array}{c}-22.339 * * * \\
(6.205)\end{array}$ & - \\
\hline $\begin{array}{l}\text { Electricity price } \times \\
\text { Quarter } 2\end{array}$ & $\begin{array}{c}1.411 \\
(1.202)\end{array}$ & - & - \\
\hline $\begin{array}{l}\text { Electricity price } \times \\
\text { Quarter } 3\end{array}$ & $\begin{array}{c}1.169 \\
(1.852)\end{array}$ & - & - \\
\hline $\begin{array}{l}\text { Electricity price } \times \\
\text { Quarter } 4\end{array}$ & $\begin{array}{l}-1.073 \\
(1.235)\end{array}$ & - & - \\
\hline South Island & - & $\begin{array}{l}68.424 * \\
(32.989)\end{array}$ & $\begin{array}{c}81.821 \\
(47.917)\end{array}$ \\
\hline $\begin{array}{l}\text { Electricity price } \times \text { South } \\
\text { Island }\end{array}$ & - & $\begin{array}{c}-3.730 * * \\
(1.583)\end{array}$ & $\begin{array}{l}-4.285^{* *} \\
(2.030)\end{array}$ \\
\hline Winter & - & - & $\begin{array}{c}-72.540 * * * \\
(19.720)\end{array}$ \\
\hline $\begin{array}{l}\text { Electricity price } \times \\
\text { Winter }\end{array}$ & - & - & $\begin{array}{l}2.388 * * \\
(0.912)\end{array}$ \\
\hline $\begin{array}{l}\text { Electricity price } \times \\
\text { Winter } \times \text { South Island }\end{array}$ & - & - & $\begin{array}{c}0.542 \\
(2.335)\end{array}$ \\
\hline South Island $\times$ Winter & - & - & $\begin{array}{c}11.952 \\
(52.485)\end{array}$ \\
\hline Observations & 720 & 720 & 720 \\
\hline
\end{tabular}

The unit of analysis is a DHB/quarter. All models also control for population, real median weekly household income, and temperature (mean daily average, minimum and maximum). Quarter 1 (the omitted category) covers January-March, Quarter 2 April-June, Quarter 3 July-September, and Quarter 4 October-December. White diagonal robust standard errors clustered by DHB are reported in parentheses. $*$, **, and *** indicate statistical significance at $90 \%, 95 \%$, and $99 \%$ confidence levels, respectively. 
Table A1.

Mapping of Line Businesses to DHB Regions

\begin{tabular}{|c|c|c|}
\hline $\begin{array}{l}\text { DHB Domicile } \\
\text { Code }\end{array}$ & DHB Name & Line Business \\
\hline 11 & Northland & $\begin{array}{l}\text { Top Energy } \\
\text { Northpower }\end{array}$ \\
\hline 21 & Waitemata & UnitedNetworks (Waitemata) \\
\hline 22 & Auckland & Vector \\
\hline 23 & Counties Manukau & Counties Power \\
\hline 31 & Waikato & $\begin{array}{l}\text { Waipa Networks } \\
\text { WEL Networks } \\
\text { Powerco (Thames Valley) } \\
\text { The Lines Company (Waitomo) } \\
\text { The Lines Company (King Country) }\end{array}$ \\
\hline 42 & Lakes & $\begin{array}{l}\text { Unison (Rotorua) } \\
\text { Unison (Taupo) }\end{array}$ \\
\hline 47 & Bay of Plenty & $\begin{array}{l}\text { Horizon Energy Distribution } \\
\text { Powerco (Tauranga) }\end{array}$ \\
\hline 51 & Tairawhiti & $\begin{array}{l}\text { Eastland Network (Eastland) } \\
\text { Eastland Network (Wairoa) }\end{array}$ \\
\hline 71 & Taranaki & $\begin{array}{l}\text { Powerco (Hawera) } \\
\text { Powerco (New Plymouth) } \\
\text { Powerco (Stratford) }\end{array}$ \\
\hline 61 & Hawke's Bay & $\begin{array}{l}\text { Unison (Hawke's Bay) } \\
\text { Centralines }\end{array}$ \\
\hline 81 & Mid Central & $\begin{array}{l}\text { Scanpower } \\
\text { Electra } \\
\text { Powerco (Manawatu) }\end{array}$ \\
\hline 82 & Whanganui & Powerco (Wanganui) \\
\hline 91\&92 & $\begin{array}{l}\text { Capital and Coast \& } \\
\text { Hutt Valley }\end{array}$ & $\begin{array}{l}\text { Wellington Electricity Lines (North) } \\
\text { Wellington Electricity Lines (South) }\end{array}$ \\
\hline 93 & Wairarapa & Powerco (Wairarapa) \\
\hline
\end{tabular}


Nelson Marlborough

111

121

123

131

141
West Coast

Canterbury

South Canterbury

Otago

Southland
Marlborough Lines

Nelson Electricity

Network Tasman

Westpower

Buller Electricity

Orion NZ

MainPower

MainPower (Kaiapoi)

Electricity Ashburton

Alpine Energy

OtagoNet

Network Waitaki

Aurora Energy (Central Otago

Clyde/Crom)

Aurora Energy (Dunedin)

Aurora Energy (Queenstown)

Electricity Invercargill

The Power Company 
Table A2.

The Effects of Electricity Prices on Hospital Asthma Admissions

DHB-Level Analysis, July 2000 - June 2009

Electricity Prices of All Retailers

\begin{tabular}{|c|c|c|c|c|c|c|}
\hline & $\begin{array}{l}\text { All asthma } \\
\text { admissions }\end{array}$ & $\begin{array}{l}\text { Infant (0-4 } \\
\text { years) } \\
\text { asthma } \\
\text { admissions }\end{array}$ & $\begin{array}{l}\text { All asthma } \\
\text { admissions } \\
\text { (excluding least } \\
\text { representative } \\
\text { DHBs) }\end{array}$ & $\begin{array}{l}\text { Infant asthma } \\
\text { admissions } \\
\text { (excluding least } \\
\text { representative } \\
\text { DHBs) }^{\mathbf{a}}\end{array}$ & $\begin{array}{l}\text { All asthma } \\
\text { admissions } \\
\text { (excluding least } \\
\text { representative } \\
\text { observations) }\end{array}$ & $\begin{array}{l}\text { Infant asthma } \\
\text { admissions } \\
\text { (excluding least } \\
\text { representative } \\
\text { observations) }\end{array}$ \\
\hline $\begin{array}{l}\text { All retailer (weighted) real } \\
\text { electricity price (c/kWh) }\end{array}$ & $\begin{array}{c}1.194 \\
(1.676)\end{array}$ & $\begin{array}{c}1.837 \\
(1.364)\end{array}$ & $\begin{array}{c}2.537 \\
(2.026)\end{array}$ & $\begin{array}{l}2.800 * \\
(1.393)\end{array}$ & $\begin{array}{c}1.449 \\
(1.619)\end{array}$ & $\begin{array}{l}2.242 * \\
(1.221)\end{array}$ \\
\hline Observations & 720 & 720 & 540 & 540 & 595 & 595 \\
\hline
\end{tabular}

${ }^{\text {a }}$ DHBs that contain data representing less than $60 \%$ of the market are excluded.

${ }^{\mathbf{b}} \mathrm{DHB}$ /quarter cells that contain data representing less than $30 \%$ of the market are excluded.

The unit of analysis is a DHB/quarter. All models also control for the relevant population, real median weekly household income, and temperature (mean daily average, minimum and maximum). White diagonal robust standard errors clustered by DHB are reported in parentheses. ${ }^{*}, * *$, and $* * *$ indicate statistical significance at $90 \%, 95 \%$, and $99 \%$ confidence levels, respectively. 


\section{Figure A1.}

\section{Estimated Regional Electricity Price Elasticities;} July 2000 - June $2009^{a}$

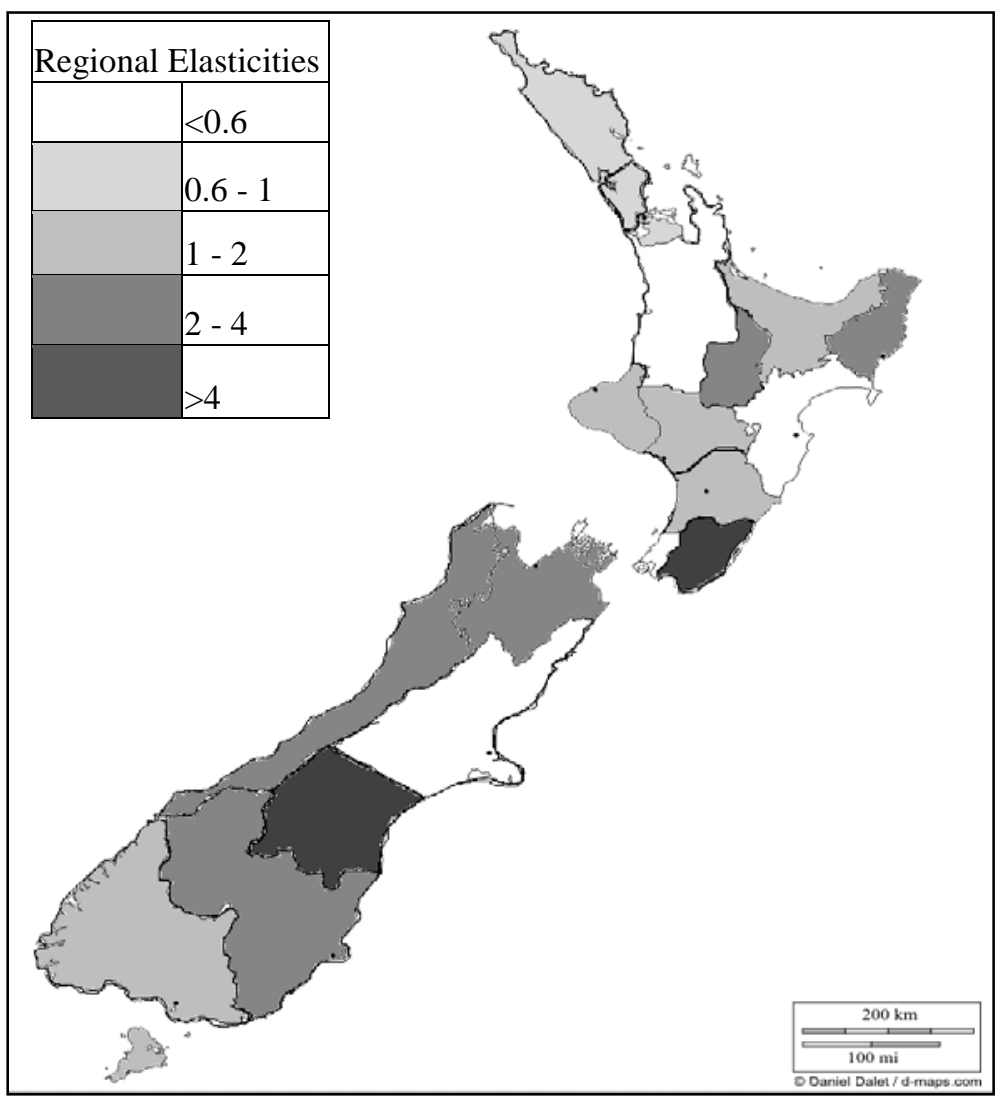

${ }^{\text {a }}$ Elasticity=change in asthma admissions for a given change in electricity price (coefficient on electricity price + regional dummy coefficient) *(average electricity price/total admissions)
Figure A2.

Percentage of Households Using Electric Heating; $2001^{\text {b }}$

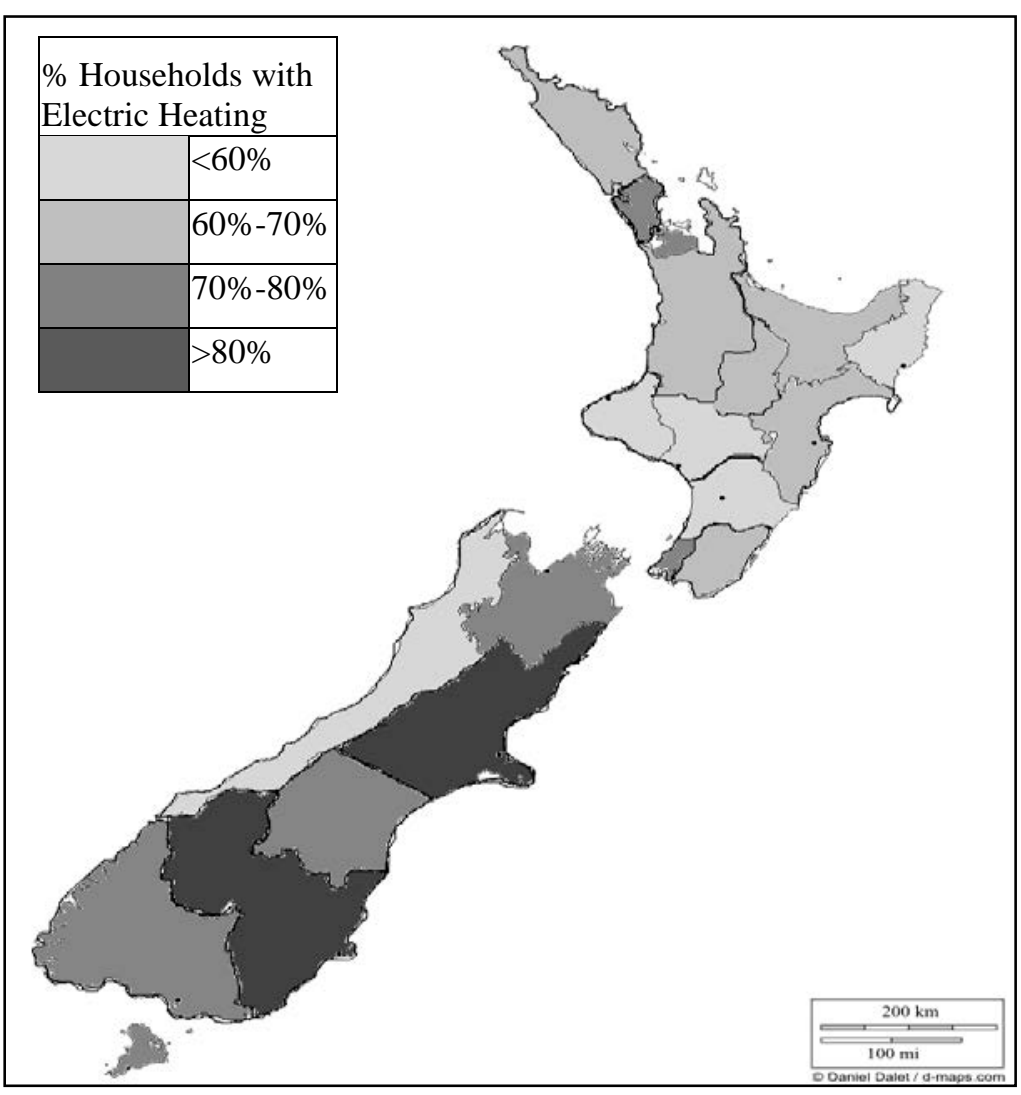

${ }^{\mathbf{b}}$ Percentage of households using electric heating $=$ number of households with electric heating/number of households *100 